Scientia Militaria vol 40, no 3, 2012, pp.13-39. doi : 10.5787/40-3-1041

\title{
Accolades and Albatrosses: The South African National Defence Force's Centenary and the Commemoration of Milestones in South African Military History
}

\author{
Deon Visser ${ }^{\bullet}$
}

\begin{abstract}
Peoples, societies, institutions and other entities frequently record their histories in terms of successive epochs, and commemorate those histories according to perceived milestones or turning points in their development. Since much of human history has been dominated by strife and warfare, national and international milestones are frequently embedded in notions of a military past. Milestones in military history may be divided into three broad categories, namely those representing significant strides in the evolution of warfare, those associated with bravery, heroic sacrifice and great loss, and those of decisive political importance. Defence forces in general, and individual military units in particular, are extremely conscious of their past and often commemorate milestones through customs, traditions, and splendid parades and ceremonial displays. This year (2012), the South African National Defence Force (SANDF) celebrates its centenary against the complex background of South Africa's long history of internal strife interspaced with participation in foreign conflicts. This article reflects on the commemoration of South Africa's military history within the context of the divergent historical heritages of the SANDF and its predecessors. It commences with a brief background on memory, identity and the commemoration of history and military history. Thereafter it outlines the commemoration of a few of the foremost milestones in South African
\end{abstract}

Lieutenant Colonel GE Visser is an associate professor of Military History at the Faculty of Military Science, Stellenbosch University (South African Military Academy). 
military history associated with the evolution of warfare, with bravery, heroic sacrifice and great loss, and with political change within its historical and current context.

Keywords: South African National Defence Force, centenary, commemoration, milestones, military history

\section{Introduction}

Peoples, societies, institutions and other entities more often than not record their histories in terms of successive epochs and commemorate those histories according to perceived milestones or turning points that marked the ebb and flow of their progression over time. Historical commemorations are usually associated with triumph and progression, but some, such as the NAAF Project, ${ }^{1}$ an online memorial to the Holocaust, serve as stark warnings against past mistakes, injustices and atrocities. Militaries are particularly conscious of their past, which they commemorate through customs, traditions and splendid parades and ceremonial displays to celebrate their achievements on the battlefield, foster esprit de corps or demonstrate their preparedness to protect national security. Robert Leckie even suggests, albeit speculatively, that the idea of commemoration and the very origins of civilisation could be traced back to the military when he writes -

it might very well have been that the warrior's desire to perpetuate the glory of his deeds in song and story was the original impetus for written language, the arrival of which is usually considered the beginning of civilized society. ${ }^{2}$

Milestones in military history are associated mostly with particular wars and battles, victories over significant enemies, or with famous commanders. The commemoration and celebration of such milestones are normally not intended as a glorification of war, but as a tribute to the genius, courage, sacrifices and achievements of soldiers and societies. The commemoration of military milestones may take many forms in addition to customs, traditions, parades and ceremonies as mentioned above. This includes national holidays, public lectures and speeches, publications, songs, poems, statues, memorials, monuments, museums, conferences, and the 
naming of medals, decorations, buildings, streets, suburbs, towns, municipalities, and institutions, to mention but a few.

Broadly speaking, milestones in military history may be divided into three categories, namely events representing significant strides in the evolution of warfare, events associated with bravery, heroic sacrifice and great loss, and events of decisive political importance. In terms of the evolution of warfare, the Battle of Cambrai in 1917, for example, marked the dawn of mechanised warfare. The "last charge of the British Light Brigade" during the Battle of Balaklava in 1854 is an example of mindless slaughter through perceived tactical folly in the face of technological advances, while the Battle of Waterloo, ending 23 years of French revolutionary wars (1792-1815) was an important political milestone in the history of Europe. It is obviously impossible, however, to place milestones in military history into watertight compartments, because the same event is often significant from more than one perspective. The Battle of Waterloo, for instance, also marks the end of French tactical superiority on the battlefield.

This year (2012), the South African National Defence Force (SANDF) celebrates its centenary against the complex background of South Africa's long history of internal strife interspaced with participation in conflicts abroad. The aim of this article is to reflect on the commemoration of South Africa's military history within the context of the SANDF centenary and the divergent historical heritages of its predecessors. It commences with a brief background on memory, identity and the commemoration of history and military history. Thereafter it outlines the commemoration of a few of the foremost milestones in South African military history associated with the evolution of warfare, with bravery, heroic sacrifice and great loss, and with political change within their historical and current context.

\section{Identity, Commemoration and the Rewriting of History}

Milestones associated with the evolution of warfare are comparatively free of emotion and are consequently often not commemorated beyond Military History classrooms and college staff rides. Some of them, such as the dropping of the atomic bomb on Hiroshima and Nagasaki, are obviously extremely loaded, ${ }^{3}$ emotionally and politically. Milestones associated with 
bravery, heroic sacrifice and great loss, and those of decisive political importance often stir up much emotion and are usually celebrated with solemn ceremonies or brilliant displays. Military milestones of perceived decisive political significance invariably evoke the most emotion and often lead to an upsurge of nationalism, sometimes even triumphant outbursts of the latter. In heterogeneous societies with a divided past, especially in the wake of recent constitutional unification where nation-building is still in its infancy, such episodes might revive old conflicts and create socio-political instability. This may be ascribed to the fact that the commemoration of history is a function of memory, myth and identity. Human experience and perceptions about the past create memory and myths, and construct identity, which, in turn, informs the production of history ${ }^{4}$ and the identification of historical milestones to serve as a basis for the commemoration of history.

Brown asserts that modern ideas about memory are rooted in classical philosophy, where "remembering is seen as inseparable from questions of moral judgement" and "remembrance is the drawing together of the past in the present for purposes of evaluation and making choices". 5 "The past", he continues, "is rarely neutral ... it comes with implications about present circumstances and future courses of action. These may appear in the form of continuities or breaks, succession or branching." ${ }^{6}$ In a similar vein, H.E. Stolten observes, "History writing is an important part of a nation state's collective memory and history is not simply a product of the past, but often an answer to demands of the present." 7 The demands of the present often lead to the exploitation of history for "ideological mobilisation". ${ }^{8}$ Pennebaker and Banasik also stress that "history ... is highly contextual" and they continue,

social psychological processes help to define history. The ways people talk and think about recent and distant events is determined by current needs and desires ... Just as the key to the future is the past, the key to the past is the present. ${ }^{9}$

These notions, as Michael Radu observes, ${ }^{10}$ bring to mind George Orwell's famous "Party slogan": "Who controls the past, controls the future; who controls the present controls the past." 11

Radu holds that politicians have appreciated the truth of Orwell's pronouncement for a long time ${ }^{12}$ and contends that "the war of ideas 
[consequently] begins with national memory". ${ }^{13}$ National memory, and hence national identity, is by and large constructed by rewriting history - a task undertaken by politicians, activists, journalists and historians, lay and professional. According to Radu, the goal of rewriting history "is always the same: to legitimize present ideas or rulers in the past ... the instruments favoured are propaganda, education in most cases, and legislation in some cases' ${ }^{14}$ In this process, grey areas in history are systematically eliminated and interpretations polarised and contemporary norms and values anachronistically applied to times, peoples and places where those norms and values have little if any validity. ${ }^{15}$ Rewriting history in service of politics changes the context of historical events, inter alia by redefining milestones. Reconstructed histories thus award new or alternative significance to historic events and create new heroes and new victories to suit new identities. ${ }^{16}$

\section{The Dominance of War in Human Society and the Commemoration of History}

Former Commander of the Allied Rapid Reaction Corps in Kabul, Lt. Gen. David J. Richards, observes, "it is a sad reflection but a truism that the history and fluctuating fortunes of nations can be tracked through military events. Nations and nation-states are formed and shaped through adversity, as are international relationships". ${ }^{17}$ This obviously echoes Von Clausewitz's idea that war is the continuation of politics by other means, and Robert Leckie's view that war rather than peace has historically been the normal state in human society. ${ }^{18}$ Since so much of human history has indeed been dominated by strife and warfare, milestones - national and international - are often embedded in military history. This is particularly true of South Africa, a country, sadly, with a rich military history. Joseph Lehmann writes:

To the Victorians South Africa was a land of surprises, a land of extremes where unparalleled discoveries in diamonds and gold coincided with incredible political and military blunders. It was a land of warfare, endemic ever since Cape Town was surrendered to the British in 1806. While the sun never set on the British Empire, the blood never seemed to dry in South Africa. Britons, Boers and blacks clashed and fought and fought again, in a fashion bewildering to those in distant centres of world civilisation. ${ }^{19}$ 
South African military history is obviously much older than British colonialism and, regretfully, continued beyond its demise. Ian van der Waag states,

South Africa's past is written in the blood of her people. From the earliest conflicts between the San and Khoikhoi through to the dawn of the "New South Africa”, South Africa's past is the story of conflict among her people; in an untold number of wars, battles, skirmishes and actions. ${ }^{20}$

Since the early inhabitants of the territory lacked a written tradition and very little oral military history has survived, milestones in pre-colonial South African military history are essentially linked to European incursion. ${ }^{21}$ The fact that much of South Africa's colonial and post-colonial military history concerns internal conflict and has predominantly been recorded from a perceived "non-indigenous" (or "non-first-nation") perspective, makes it particularly susceptible to diverging interpretations, claims and vigorous dispute. The SANDF was born within this diverging historical discourse on 27 April 1994, as it was created through the integration of the statutory defence forces of the RSA (SADF) and the formerly so-called independent black homelands (Transkei, Bophuthatswana, Venda and Ciskei), and the non-statutory forces of the African National Congress (MK), the Pan Africanist Congress (APLA) and the KwaZulu-Natal Self Protection Force.

The SANDF as such is just eighteen years old, but by claiming 1912, the establishment date of its oldest statutory predecessor, the Union Defence Forces (subsequently the South African Defence Force (SADF), as its actual date of birth, the SANDF celebrates its one-hundredth birthday this year. That date can also, albeit indirectly, be linked to the birth of the ANC's military wing, Umkhonto we Sizwe (MK), although the latter was only founded in 1961, since 1912 was also the year in which the ANC itself was established. The history of the SANDF goes by extension, however, infinitely further back than a hundred years through the historical legacies imbedded in its identity by the integration of the various statutory and nonstatutory militaries. South Africa's pre-1912 military history influenced or informed the historical memory, heritage, identity and traditions of the former SADF and is still influencing those facets of the SANDF, but from a different perspective. This is evident, inter alia, in the naming and renaming 
of military buildings and training facilities, as well as ships, medals and decorations. Hence pre-1994 milestones in military history are still relevant to the SANDF today.

\section{South African Milestones in the Evolution of Warfare}

Indigenous warfare developed in South Africa, at least in terms of weapons, in much the same way as elsewhere in the world, although not simultaneously with, for example, developments in Europe. Specific milestones in the pre-colonial evolution of warfare in South Africa are not easy to identify. Shaka's military leadership, reforms and innovations have long been celebrated as a milestone in South African and African military history. Yet, Dan Wylie found that most of this is pure myth. Shaka, he maintains, did not invent the famous "ox head" military formation. It already existed before Shaka started using it, and there is no evidence that he even used it on more than one occasion. Shaka also did not invent the short stabbing spear for close combat as is widely held. Shaka most probably refined some of these military innovations but he did not initiate them. Moreover, his alleged decisive victory over the Ndwandwe at Gqokli Hill, widely praised as his greatest military triumph, according to Wylie, never happened. It is a flight of Ritter's imagination that found its way into history texts from his novel Shaka Zulu. ${ }^{22}$ The popular image of Shaka as military genius and/or brutal, bloodthirsty ruler and conqueror, the "cynosure of Zulu nationhood, and the epitome of African brutality", ${ }^{23}$ Wylie asserts, survives because it is "so intriguing, so dramatic, so archetypal, and sometimes so politically useful". ${ }^{24}$ Though milestones in the evolution of warfare are normally devoid of emotions or politics, it is thus clearly not always the case, especially where fact and legend meet.

Since firepower is at the heart of conventional warfare, it is not surprising that it was also at the heart of milestones in the evolution of warfare in South Africa. In Voortrekker history, Vegkop (1836), Blood River (1838) and similar battles stand out for the fact that concentrated firepower from the protection of reinforced wagon laagers offered a solution to the numerical superiority of the Voortrekkers' indigenous enemies. The First Anglo-Boer War (1880-1881) produced two noteworthy milestones associated with the ever-increasing devastation of modern firepower. Military units had carried their flags, banners and regimental colours into 
battle since ancient times in order to identify individual units and to serve as a rallying point amidst the noise and chaos of battle. Regimental colours were frequently destroyed or badly damaged in battle and often captured by the enemy. Worse still, in the words of Lehmann, "the two unfortunate subalterns selected to carry the colours ... into action were almost certain to be downed; and those rushing forward to pick up the 'soul' of their unit would in all probability suffer a similar fate". ${ }^{25}$ Mainly as a result of the influence of British military reformer Sir Garnet Wolseley, who held that "any general who condemned an officer to death by ordering him to carry a standard into battle against high-powered rifles 'should be tried for murder", ${ }^{26}$ the British army abandoned the practice of carrying regimental colours into battle. The last British Regiment to do so was the $58^{\text {th }}$ Regiment during the Battle of Laing's Nek on 28 January 1881. Since then, colours are left safely at home when units go to war. ${ }^{27}$ The second firepower-related milestone in the development of warfare during the First Anglo-Boer War also took place during the Battle of Laing's Nek: the British soldiers dyed their white helmets and belts brown with cow-dung and coffee grounds to make them less conspicuous targets. Not smelling too good for a few days was much better than inviting Boer fire! ${ }^{28}$ By the Second Anglo-Boer War (1899-1902) the British had done away altogether with their brightly coloured uniforms and took to the field in khaki. ${ }^{29}$

Firepower also produced two significant milestones in the evolution of warfare during the Second Anglo-Boer War. The Battle of Magersfontein (11 December 1899) is often associated with the birth of the type of trench warfare that dominated the First World War on the Western Front in the face of the enormous firepower of accurate, long-range magazine rifles that had made the defensive stronger than the offensive. ${ }^{30}$ The dominance of the defensive over the offensive in turn triggered another milestone, namely a closer integration of infantry and artillery tactics. In the past, the artillery bombarded the enemy in preparation of the infantry attack and ceased fire when the latter commenced. This made the infantry advance a suicidal exercise in the face of the high volume of fire maintained with the accurate, long-range magazine rifles from the safety of trenches and other forms of cover. The solution Lord Buller and his officers found on the Thukela front in February 1900 was to keep the head of the enemy down with artillery fire during the infantry advance. This was the birth of the so-called "creeping" or "rolling" artillery barrage ahead of the infantry which supported them 
throughout the battle instead of only softening the enemy before the infantry advance. ${ }^{31}$ The opposing forces perfected the rolling or creeping artillery barrage on the Western Front during World War I until, in the words of John Terraine, it became "a (moving) curtain of bursting shells ... nailing the enemy into his deep shelters until the last moment when the attacking infantry was virtually on top of him". ${ }^{32}$

The Battle of Magersfontein stands out as an extremely "black day" in the history of the British Army, particularly for the Black Watch. Buller's breakthrough on the Thukela front on Majuba Day 1900, the commemoration of the decisive Boer victory of the First Anglo-Boer War, was a bitter irony for the Boers and a moral triumph for the British. ${ }^{33}$ Purely from the perspective of milestones in the evolution of warfare, however, both battles are devoid of politics and emotion.

Whatever milestones in the evolution of warfare South Africa's Border War produced, such as the claim that the first ever close air support to South African ground forces by helicopter gunships at night took place at Ongiva during Operation PROTEA in August $1981,{ }^{34}$ were equally devoid of emotion and politics. In sharp contrast, the first confirmed killing and also the first capture of Russian military personnel by the South African forces on the same occasion, ${ }^{35}$ proving Soviet combat involvement in Angola to the Western world, was, of course, of great political significance.

\section{Milestones of Bravery or Heroic Sacrifice}

Milestones of bravery, heroic sacrifice or great loss of human life in war often relate to desperate defence of a cause or position, but may also refer to bold offensive action to take a key position against great odds. Such milestones often also contain an element of sudden disaster or mindless slaughter, often through superior numbers, superior technology or superior (state) power. A systematic search of South Africa's long history of ethnic and racial strife and violence from pre-colonial times to 1994 would reveal many such examples, be it through oral tradition or written record. Before the arrival of the Europeans, conflict occurred between South Africa's first peoples, the San, the Khoikhoi and the Bantu-speaking groups, but very little is known about such conflicts, their intensity and casualties. ${ }^{36}$ Some authors are of the opinion that such clashes were not particularly bloody, but 
there is just not enough knowledge available to come to a firm conclusion. Even if fragments of this early South African military history have survived through oral tradition, it is not commemorated, except perhaps in tale and song in rural communities. The two rather inconclusive "formal" wars fought during the Dutch subjugation of the Khoikhoi (1659-1660 and 16731677) are obviously significant milestones in South Africa's political history, but are arguably not primarily remembered as milestones of bravery, heroic sacrifice or great loss of human lives because they were comparatively low in intensity and not extremely bloody. During the first Dutch-Khoikhoi War, the Dutch authorities actively tried to limit loss of life amongst the Khoikhoi by offering a reward of 40 guilders to expedition members for every Khoikhoi captured and only half that amount (20 guilders) for every one killed. ${ }^{37}$

The Dutch wars against the San, who committed many atrocities against the Trekboers in their relentless resistance to the penetration of their traditional habitat, were brutal and indeed amounted to mindless slaughter. A milestone in this regard was the wide-ranging punitive expedition under Commandant Rudolph Opperman sent in 1774 by the Cape government against the San on the northern frontier. Since the San rejected every attempt at negotiation, the Cape government sanctioned the merciless slaughter of men, women and children alike on the battlefield. Opperman's commando killed a total of 503 San and captured 241 women and children, who were forced into labour. ${ }^{38}$

The conflict amongst the European settlers and the Xhosa on the Cape's eastern frontier lasted a hundred years, from 1779 to 1879, and erupted in nine bloody frontier wars: two under Dutch rule and the rest under British rule. ${ }^{39}$ Much mindless slaughter took place on both sides during and between these nine milestones. For Xhosa people, King Hintsa ka Phalo's controversial, contested killing and alleged beheading by British soldiers during the Sixth Frontier War (1835) still stands out vividly in this context. ${ }^{40}$ In the Voortrekker-Zulu conflict of the early nineteenth century, the massacre of Piet Retief and his men at Ungungundlovu, and the Boer families along the Bloukrans and Boesmans Rivers by the Zulus and the slaughtering of Zulu warriors by the Voortrekkers at Ncome River (Blood River) ${ }^{41}$ are recalled with great sadness by the respective sides. Amongst the more recent of such grim milestones are the mass slaughtering of almost 
860 British soldiers by Zulu warriors at Isandlwana in $1879,{ }^{42}$ the death of tens of thousands of South Africans, both black and white, in British concentration camps during the Second Anglo-Boer War, ${ }^{43}$ the annihilation of some 750 white South African soldiers at Delville Wood in 1916, ${ }^{44}$ the drowning of over 600 black South Africans during the sinking of the SS Mendi in 1917, ${ }^{45}$ the slaying of black demonstrators at Sharpeville and Langa in 1960, and the massacre of black students in Soweto in 1976. ${ }^{46}$ The events at Sharpeville, Langa and Soweto are mentioned here as "military" milestones against the background of revolutionary and counterrevolutionary violence. However politically loaded the memory of these events is, all of them are sad milestones of extreme human sacrifice and as such at least to some degree respected across political and ideological divides today.

\section{Military-Political Milestones}

Since the early inhabitants of the territory that forms the Republic of South Africa today lacked a written tradition and very little oral history has survived, milestones in pre-colonial South African military history are essentially linked with European incursion. The defining of military milestones of political significance depends, furthermore, very much upon the context of world history on the one hand and the local political "flavour of the moment" on the other. South Africa's nineteenth-century English historians focused on settler history and defined historical milestones within that Eurocentric context. On their heels followed the imperialistic school who stressed the progressive, "civilising" impact of the British Empire on the African continent. Subsequently, a strong nationalist Afrikaner historiography developed which milestoned South African history in terms of the Afrikaner's struggle against British domination and black peril in their quest for political independence in the interior. ${ }^{47}$ In settler and imperialist history, and more so in Afrikaner history which "provided the ideological substructure for the apartheid ideology and legitimised white domination”, Georgi Verbeeck contends

there was no room for the ... historical experience of the non-white... population group[s], not in the pre-colonial period nor thereafter ... non-whites were not considered important enough to be accorded a history of their own ... blacks disappear from the field of vision of an image of history dominated by 
whites, unless when portrayed as enemies and opponents on one of the countless battlefields. ${ }^{48}$

With the advent of the "New South Africa" Verbeeck observes:

Inevitably, the abolition of apartheid also has far-reaching consequences for the historical culture of this country. The enlarged image of history fits into a political strategy aiming to bring about a new national consensus. The socalled Rainbow Nation is looking for an image of history which can be linked to the new profile of a multicultural democracy. ${ }^{49}$

Producing an inclusive, consensual image of South African history is an elusive, if not completely unachievable objective because it requires the accommodation, to some degree at least, of many different approaches and myths caught up in the different sectors of society's sense of history and their understanding of the past. What Tony Ullyatt says about writings on mythology, is also true of trying to distil a consensus history from South Africa's divided past:

... the problem of distorting presumptions, biased perspectives, ideological and/or academic stances seems inevitable. These stances introduce a wide variety of arguments designed primarily as self-justification. While no one would want to deny the right of the writer to opt for what $\mathrm{s} / \mathrm{he}$ considers appropriate theoretical contextualisation for her/his approach to the subject, the existence of such a diversity of approaches tends to muddy the waters rather than purify them. While the best way to un-muddy the waters is to let them stand still, such a patient Buddhist approach seems beyond the capacity of most writers. $^{50}$

Socio-political impatience to hammer South African history into a mould that meets present demands leaves no room for somewhat "unmuddying" South African history by allowing the passage of time to temper emotions and impose a more "objective" perspective. "Public history", Grundlingh holds, "often tends to range free, largely impervious to the arcane workings of the historical profession". ${ }^{51}$

South Africa's long history of strife and violent conflict places military history centrally in the process of finding "an image of history which can be linked to the new profile of a multicultural democracy". ${ }^{52}$ Mills and Williams list Blood River, Isandlwana/Rorke's Drift, Majuba, 
Colenso, Delville Wood, El Alamein and Cuito Cuanovale as " 7 Battles that shaped South Africa". ${ }^{33}$ Many other battles and events in South Africa's past could obviously be added to this list as military-political milestones. Kadar Asmal regards this selection as useful for three reasons. Firstly, they "encapsulate South Africa's political and ideological divisions and preoccupations over the past two centuries: Boer versus Zulu, Zulu versus Britain, Britain versus Boer, South Africa versus Germany, imperialist versus republican, the West versus the Soviet bloc and, critically, liberation against apartheid". ${ }^{54}$ Secondly, these battles, as military-political milestones, bring home the important point that such events, set in a contested history such as South Africa's, often signify completely different things to different people. To quote Asmal again, for one side, Blood River might have been a symbolic victory, for the other it was not only known by a different name - Ncome River to the Zulu nation - but also signalled the beginning of a long period of hostility and oppression. ${ }^{55}$ Thirdly, it illustrates how the history is rewritten to give new meaning to the same milestones.

An early example of an event illustrating the three points mentioned above is the Khoikhoi victory over the forces of the Portuguese Viceroy, Admiral Francisco de Almeida, in Table Bay in 1510, when they attacked a Khoikhoi settlement. ${ }^{56}$ From a Eurocentric perspective, this was a rather insignificant event that received comparatively little attention. With the rise of African nationalism in the twentieth century, and the consequent reinterpretation and rewriting of South Africa's history, the event however acquired significance as the earliest black resistance to European intrusion and oppression. ${ }^{57}$

An important military-political milestone in South Africa's colonial history was the Battle of Blaauwberg on 8 January 1806. It established British rule in South Africa for over a century and led to much conflict and bloodshed during the nineteenth and early twentieth century. Despite its impact on South African history, this milestone has by and large faded away into insignificance with the exodus of the British. In the wake of British colonialism, Afrikaner nationalism dictated the identification and commemoration of milestones in South Africa's military past in terms of the Afrikaner's struggle to overcome black resistance to their penetration of the interior and their resistance to British political domination. In the case of 
the former, the Boer victories against the Ndebele at Vegkop in 1836 and the Zulu at Blood River on 16 December 1838 through perceived divine intervention and concentrated firepower, stand out. Subsequently known as the Day of the Vow or the Day of the Covenant, or, colloquially, 'Dingaan's Day', 16 December became a public holiday and Afrikaners celebrated it annually with great dedication. The Boer victory at Congella (1842) and their defeat at Boomplaats (1848) became two early milestones in the Afrikaner's armed resistance to British domination, followed by the two wars of independence in 1880-1881 and 1899-1902. The Boer victory at Majuba on 27 February 1881 resonated throughout South Africa, and S.J. du Toit and others hailed it as the moment when Afrikaner nationalism really took root. ${ }^{58}$

The Second Anglo-Boer War, milestoned as the Second War of Independence in Afrikaner history, in itself also represents several broader, international milestones. "Based as it was on the [British] need to plunder gold from the Boer Republic", Hussein Solomon observes, "it was the 20th century's first resource war". ${ }^{59}$ The Second Anglo-Boer War was also the first major anti-colonial war on the African continent and it indeed "tarnished the credibility of the British Empire as the world's superpower". ${ }^{60}$ On the other hand, the war, according to Ina Snyman et al. produced "an intolerant brand of Afrikaner nationalists whose more radical adherents came to power in $1948 \ldots$ and the atrocities committed in the name of apartheid under their rule caused [particularly black] people to ignore the Anglo-Boer War" ${ }^{\prime 1}$ as a milestone in the anti-colonial struggle in Africa. Eurocentrism and racial prejudice on the other hand caused both Boer and Briton to ignore the significant involvement of black people in the war for a century. ${ }^{62}$

South Africa's close ties with Great Britain after unification in 1910 led to her participation on the side of the Allies under the banner of freedom and democracy during the two World Wars. The South African government captured the Union's contribution to these wars in official histories. The Union commemorated inter alia the supreme sacrifice of her forces at Delville Wood during the First World War and their contribution to the allied victories in North Africa and Italy during the Second World War. When the National Party gained control in 1948, it pushed aside the Union's contribution to the two World Wars as "Empire service" and focused on the 
military milestones of Afrikaner history in their conflict with indigenous peoples and in their resistance to British domination. ${ }^{63}$

According to the late Prof. Elize Botha, former Chancellor of Stellenbosch University, by the mid-1950s, some of the negative feelings regarding the Union's participation in the two World Wars had already worn off amongst the general public. She writes:

Memories of the Second World War were still very strong ... Especially the young men of the 1950s remembered it well. Whatever their politics or view of life was, as the opposition to South Africa's participation in the war wore off they were in time able to identify with the "Springbucks" (as the soldiers of the South African divisions were called) who participated in the battles in North Africa ... and subsequently invaded Italy with the British Eighth Army. ${ }^{64}$

The National Party's rise to power coincided with a major change in the context of world history, namely the beginning (or some might argue the intensification) of the Cold War, which influenced the identification and commemoration of South Africa's military milestones significantly. After unification in 1910, South Africa's racial policies ignited an internal black liberation struggle that escalated dramatically under Nationalist rule and eventually threatened South Africa with complete international isolation. Hence the South African government went to great lengths to remind the Western world that South Africa was a valuable partner in international crises and that the country should not be pushed aside because of its internal policies. The military-political milestones of the Afrikaner obviously remained important, but the Nationalist government now emphasised South Africa's contribution to international milestones in the war against the 'forces of darkness'. After its initial apathy towards South Africa's contribution to the Allied war effort during the First and Second World Wars, the Nationalist government went to great pains by the 1970s to remind the world of the Union's efforts and sacrifices in the interest of freedom and democracy during the World Wars. ${ }^{65}$ Battles such as Delville Wood and El Alamein together with the airlift of supplies to the Polish resistance, the so-called Warsaw Concerto, became important milestones in South Africa's military history once more. More importantly, the apartheid government exploited the prevailing Western view that the Soviet Union, in pursuance of its aim of world domination, was supporting and exploiting dissatisfaction, insurrection and liberation struggles across the globe to 
expand its influence, gain footholds and strangle the Western powers. ${ }^{66}$ The apartheid regime portrayed both the internal black liberation struggle, spearheaded by the African National Congress (ANC) and the Pan Africanist Congress (PAC), and the hostility of the newly independent or self-governing African states towards South Africa as local manifestations of the global communist onslaught against the West. ${ }^{67}$ The RSA consequently depicted itself as the bulwark of Western democracy against the spread of communism in Southern Africa and emphasised its historic role in the Western effort to contain communism, ${ }^{68}$ highlighting its contributions to the Berlin Airlift (1948-1949), the Korean War (19501953) and the Angolan Civil War (1975) ${ }^{69}$

As the counter-revolutionary war escalated by the 1970s, the apartheid government began to emphasise the contribution of so-called coloured, Asian and black (African) South Africans during the two World Wars. Hence, the gallant action of the Cape Corps, a "coloured" regiment, at Square Hill in Palestine (September 1918) and the sacrifice of African lives with the sinking of the SS Mendi (21 February 1917) eventually took up their places as milestones in South African military history next to Delville Wood and other "white" battles and events. This recognition was amongst other things motivated by the need to recruit black soldiers to relieve the Border War's pressure on white manpower and the desire to motivate black people to join the war against "communist" insurgents. ${ }^{70}$

Apartheid South Africa's 23-year (1966-1989) Border War in northern Namibia and Angola lasted longer than America's Vietnam War, and its history and milestones are in many ways as controversial and contested as those of the latter. Commemorated as a highly successful airborne operation against a Swapo military base by the former South African Defence Force (SADF), the attack on Cassinga (4 May 1978) stands out to their opponents as the massacre of hundreds of Namibian refugees, mostly women and children. ${ }^{71}$ Both the former SADF and its Fapla/Plan (Swapo) opponents claimed the Battle of Cuito Cuanovale (1987-1988) as a victory. The conflicting claims regarding Cassinga and Cuito Cuanovale have caused much reviewing and rewriting of the history of these two events. The facts are still in dispute, but both remain highly politicised milestones in South African military history ${ }^{72}$ which still evoke divisive 
sentiments in South African society because of the close historical links between the former liberation movements in Southern Africa.

With the termination of the Border War and South Africa's internal liberation struggle in 1989/90, and the subsequent establishment of an allinclusive defence force in 1994, the SANDF's focus has shifted to peace missions on the African continent. Naturally, South Africa's next military milestone is to be found in that sphere. In September 2009, the SANDF proudly celebrated ten years of involvement in peace missions on the African continent that started with the deployment of a capital liaison officer in Kampala in the Democratic Republic of the Congo (DRC) in September 1999. ${ }^{73}$ The SANDF and Botswana Defence Force (BDF) invasion of Lesotho a year earlier (Operation Boleas, September 1998), which arguably also fits into the realm of peace missions, is not even mentioned in the SANDF's commemorative brochure. This seems to be a result of it being a Southern African Development Community (SADC)-mandated operation instead of a United Nations (UN)-mandated mission. However, the whole mandate controversy regarding Operation Boleas and the unfortunate blunders of that intervention perhaps also render it a less than commemorable milestone from a government and Department of Defence perspective.

\section{Yesterday's Milestones Today}

Edward Said captures the complexities of commemorating milestones from a divisive past to a "united" present, such as South African's fledgling democracy, when he observes:

Appeals to the past are among the commonest of strategies in interpretations of the present. What animates such appeals is not only disagreement about what happened in the past and what the past was, but uncertainty about whether the past really is past, over and concluded, or whether it continues, albeit in different forms, perhaps. This problem animates all sorts of discussions about influence, about blame and judgement, about present actualities and future priorities. ${ }^{74}$

Christopher Clapham stresses that liberation struggles change the selfperception, identity and thought processes of those who participated in them. The liberation struggle remains intensely alive in the memory of its 
leaders long after they had taken over the government of the country and they carry with them an unshakable conviction of the justness of their cause and their responsibility to continue to pursue the objectives for which many have fought and died. ${ }^{75}$ It is their heart-felt duty to constantly rekindle the memories of their constituency to keep the spirit and vision of the liberation struggle alive. South Africa has consequently, in the words of A.K. Hlongwane, been "in the grip of a 'memory boom'..." since 1994. These memories as "the 'physical markers of past violence and repression'... [in the] 'arena of societal struggles over memory","76 led to the establishment of several new museums, amongst others the Robben Island Museum, the District Six Museum, the Apartheid Museum, the Hector Pieterson Memorial and Museum, the Sharpeville Exhibition Centre and Monument, and the Freedom Park project. They also gave rise to popular annual commemorations of Human Rights Day (21 March, previously known as Heroes Day or Sharpeville Day), Freedom Day (27 April), Workers Day (1 May), National Youth Day (16 June, previously known as Soweto Day), Women's Day (9 August), Heritage Day (24 September) and the Day of Reconciliation (16 December, formerly known as the Day of the Vow or Dingaan's Day). ${ }^{77}$ Y. Seleti holds that national holidays, which "commemorate significant milestones in the struggle for freedom in South Africa, helps the nation to appreciate the importance of history, heritage and memory in the crafting of the present and future of this country". ${ }^{78}$ In his view it "attempts to counteract amnesia as the basis for nation-building". ${ }^{79}$

The black "memory boom" explicitly endeavours to redress the domination of white, particularly Afrikaner, symbols of historical commemoration by drawing, in the words of former ANC Premier of Limpopo Province, Sello Moloto, “a connection between ... colonial resisters (such as Kings Makhado, Sekhukhune and Nghunghunyane) and the liberation struggle in South Africa” ${ }^{80}$ Moloto observes:

The rest of the South African cultural and historical landscape is biased towards commemorating the "Anglo-Boer Wars" and therefore does not give deserved recognition to the role played by African chiefs in defence of their Chiefdoms. [These kings] were brave individuals who were the pioneers of the liberation struggle. Long before the ANC was born these kings fought the wars of resistance against colonialism and dispossession ... Makhado was never defeated nor subjugated by the Boers. It is for these reasons that they should be commemorated. ${ }^{81}$ 
Several other names, including that of Chief Hintsa (Xhosa), mentioned earlier, and Kings Dingaan (Zulu), Moshweshwe (Sotho) and Malebogo (Hananwa/Batlokwa) may, of course, be added to Moloto’s list. ${ }^{82}$

In February 2012, as head of state and commander-in-chief of the SANDF, President Jacob Zuma endeavoured to put the commemoration of the sinking of the SS Mendi in post-1994 perspective by instituting 21 February, the day of its sinking, as Armed Forces Day. Henceforth "the entire nation" is expected annually, on this date, "to pause and pay tribute to all members in uniform who have taken it upon themselves to serve the people of South Africa and defend the Constitution of the country, with their lives". ${ }^{83}$ As a tale of heroic sacrifice in which history and myth meet to create "an extraordinary account ... of war bravery" ${ }^{84}$ the sinking of the SS Mendi evokes compassion over a wide spectrum and is consequently a suitable milestone for public commemoration. In the context of the liberation struggle, the Department of Defence and the SANDF, furthermore, commemorate the 1976 Soweto uprisings every year through the National Youth Day celebrations. This emotional milestone can hardly be depoliticised, but the Department of Defence endeavours to commemorate it in a constructive way in the spirit of nation-building. Hence the Department's 2012 theme for its Youth Day celebrations was "Entrenching our democracy by promoting youth cohesion through discipline and sports”. ${ }^{85}$

In Hlongwane's view, however, the commemoration of 16 June as National Youth Day has

... like all other national days of commemoration ... failed to bring South African youths and the population in general together across the colour line. Indeed, the commemoration of National Youth Day is seen as an affair for Africans. The opposition parties whose constituency is largely within white communities have since 1994 been commemorating the 1976 uprisings, merely as part of the political agenda to attract African voters. 86

Though this is a sweeping statement, recent images of such commemorations on national television seemed to support this perspective of indifference on the part of other sectors of South African society. Furthermore, while liberation struggles often succeed in unifying subjugated people against oppressive regimes, underlying differences as often emerge 
again once the liberation struggle has been won. ${ }^{87}$ Hence, Youth Day celebrations have also not managed to sustain unity amongst the various former liberation movements. ${ }^{88}$ The Socialist Party of Azania, for example, asserts that:

Every year, since the whole of South Africa rose in protest against the failure of the first democratically elected government to recognise or even commemorate June 161976 when they took office in 1994, they have ever since then made it their business to make the loudest of noises about the day though with little commitment to it. They have deliberately downgraded it, depoliticised it and christened it "Youth Day", a day of mirth, drink and general fun where the government spends millions of rands entertaining the youth through song and dance. The day, in line with politics of "reconciliation" has been made "user friendly" to allow the smooth participation of the perpetrators and the victims. The sombre and reflective mood of commemorations has been stripped from the day. They do not commemorate June 16, they do not remember and honour the sacrifices of those who gave their lives for our liberation instead they have chosen an innocuous way of doing it, they celebrate it. ${ }^{89}$

Alongside these notions of pessimism some authors hold that the advent of the "New South Africa" in 1994 has indeed established some common ground and reciprocal accommodation in terms of military milestones between black and white. Snyman et al., for instance, are of the opinion that the new political dispensation has made the Second Anglo-Boer War "okay" 90 since Europeans now acknowledge the full involvement of black people in the war, while some black people now recognise it as the first major anti-colonial war in Africa and acknowledge the Boers as "freedom fighters". ${ }^{91}$ Furthermore, the acceptance of the establishment date of the former SADF as the SANDF's birthday may to some extent be construed as an act of accommodation, reconciliation and nation-building in itself on the part of government. Recent ANC resistance to the equestrian statue of General Louis Botha, in the uniform of the former Union Defence Forces, at the entrance to Parliament has, however, demonstrated how divisive pre-1994 milestones still are. Though Botha left a large footprint in South African military history, his presence in front of Parliament is due to the fact that he was the first premier of the Union of South Africa, not because of his military exploits. On that basis, ANC Member of Parliament, Thandile Sunduza, stated in August 2012 that Botha's statue belongs rather 
in the Apartheid Museum and should be replaced by a statue of former President Nelson Mandela, "because he represents all of us". ${ }^{92}$ The general response of parliamentarians from other political parties was that Mandela indeed deserves a place in front of the building, but that Botha should stay because he was also part of South Africa's history and that part of the past cannot simply be wished away or erased. ${ }^{93}$ Similar sentiments are expressed regarding the current quest for the renaming of cities, towns and streets, etc., to allegedly "wipe out” South Africa's pre-1994 history. ${ }^{94}$ And, every now and then, until recently, when a court ruling stopped him, former ANC Youth League leader, Julius Malema commemorated the liberation struggle by singing, in public, "Dubul' ibhunu" ("shoot the Boers"), which threatened to rekindle old divisions. ${ }^{95}$ Similar emotions were stirred on 4 November 2012 when President Jacob Zuma's favourite and politically controversial struggle song "Awulethu Mshini Wami" ("bring me my machine gun") "was blaring from a sound system" 96 as ANC supporters stopped a march led by Democratic Alliance leader, Helen Zille, towards President Jacob Zuma's homestead in Nkandla. Zille's march followed a public outcry over an alleged government expenditure of some R200 million to upgrade that residence. ${ }^{97}$

On the other side of the hill, Dan Wylie bitingly observes, "certain die-hard Afrikaners continue to celebrate ... the 1838 Battle of Blood River ... even today" ${ }^{98}$ During the bitter conflict over the renaming of the town of Louis Trichardt, commemorating a Voortrekker leader, to Makhado, commemorating a Venda king's resistance to colonialism, the newly erected statue of King Makhado in that town was painted in the colours (orange, white and blue) of the old South African flag. Though the culprits were never caught and some commentators claimed that this act of vandalism was committed by "hooligans and should not be viewed in terms of 'white against black' despite the obviously racial associations of the flag and colour symbolism"99 the suspicion of right-wing involvement lingered on. The fact is that the wounds of the South African liberation struggle have not healed yet and reciprocal notions of mistrust and cultural-political entitlement or deprivation will probably prevail in South African society for decades to come. Emotions still run high and memories of the liberation struggle will continue to be mobilised for political ends. 


\section{Conclusion}

South Africa's divided past makes it impossible for the country in general and the SANDF in particular to consider the past hundred years only when they celebrate the latter's centenary; it requires due recognition of the much longer separate and collective histories in which the perceptions and sense of identity of the various sectors of society are imbedded. Milestones in the evolution of warfare are comparatively free from political and emotional baggage and could be recognised and commemorated by people with diverging socio-political backgrounds and convictions. Milestones of bravery and heroic sacrifice might be more problematic because they often involve perpetrators and victims or winners and losers, and thus politics and emotions. Common respect for human courage, suffering and sacrifice might nevertheless remove many obstacles in the defining and commemoration of such milestones, for example the sinking of the SS Mendi and the Battle of Delville Wood. Commemorating military-political milestones such as Cassinga, Cuito Cuanovale and others, is quite different. The complexities in commemorating such contested, inherently divisive, military-political milestones make it practically impossible to find complete "feel-good" 100 consensus across the socio-political spectrum. Accolades from one perspective easily become albatrosses from another. South Africans would therefore do well to acknowledge and respect the different perspectives regarding such milestones, and commemorate them for what they can learn from them about themselves and the nation to which they belong for the sake of building a better common future for all beyond the paralysing grip of their divided past.

$1 \quad$ NAAF stands for "Never Again, Always and Forever". The project's goal is "to use the Internet as a unique and eternal resource, presenting Holocaust fact and information to any person that has online access". NAAF Project. <http://www.neveragain.org/> Accessed on 9 November 2012. R Leckie. Warfare. New York: Harper \& Row, 1970, 6. Also quoted in GE Visser. "Die aard, studieveld en funksie van die krygsgeskiedenis". Scientia Militaria 23/2. 1993. 1.

3 See I Buruma. The wages of guilt: Memories of war in Germany and Japan. London: Vintage, 1995 and RJB Bosworth. Explaining Auschwitz and Hiroshima: History writing and the Second World War 1945-1990. London: Routledge, 1994.

$4 \quad$ See for example JWN Tempelhoff. "Writing histories and creating myths: Perspectives on trends in the discipline of history and its representations in 
some South African historical journals 1985-1995”. Scientia Militaria 27. 1997. 121-147 and A Grundlingh. "Mutating memories and the making of a myth: Remembering the SS Mendi Disaster, 1917-2007”. South African Historical Journal 63/1. 2011. 20-37.

SD Brown. Learning, remembering and meta-cognitive/communication skills. 2009. <http://www.beyondcurrenthorizons.org.uk/learningremembering-and-meta-cognitivecommunication-skills> Accessed on 27 January 2010.

Ibid.

HE Stolten. "History in the new South Africa: An introduction". In HE Stolten (ed), History making and present day politics: The meaning of collective memory in South Africa, Uppsala: Nordiska Afrikainstitutet, 2007, 6-7.

Stolten op. cit., p. 7.

JW Pennebaker \& BL Banasik. "On the creation and maintenance of collective memories: History as social psychology”. In JW Pennebaker, D Paez \& B Rimé (eds), Collective memory of political events: Social psychological perspectives, Mahwah, NJ: Lawrence Erlbaum, 1997, 3.

M Radu. History and political games. November 2008. $<$ http://www.fpri.org/enotes/200811.radu.historypoliticalgames.html>

Accessed on 26 October 2009.

G Orwell. Nineteen eighty-four. London: Penguin, 1984 (originally published in 1949), 34.

Radu op. cit.

Ibid.

Ibid.

Ibid.

See for example AK Hlongwane. "Commemoration, memory and monuments in the contested language of black liberation: The South African experience”. The Journal of Pan African Studies 2/4. 2008. 136.

DJ Richards. "Foreword". In G Mills \& D Williams (eds), 7 battles that shaped South Africa, Cape Town: Tafelberg, 2006, 9.

Leckie op. cit., p. xi.

JH Lehmann. The First Boer War. London: Jonathan Cape, 1972, 13.

IJ van der Waag. "The writing of military history in South Africa”. South African Military Yearbook 1997. Pretoria: South African Military History Consultants, 1997, 5.

Van der Waag op. cit., p. 5.

D Wylie. Myth of iron: Shaka in history. Pietermaritzburg: University of Natal Press, 2006, 1-2, 173, 216-217, 380; D Wylie. Savage delight: White myths of Shaka. Pietermaritzburg: University of Natal Press, 2000, 1, 8, 22931, 240.

Wylie, Savage delight op. cit., p. 1.

Wylie, Myth of iron op. cit., p. 2.

Lehmann op. cit., p. 151.

Ibid., p. 151, footnote. 
Ibid.; Regimental colours. <http://www.theregiment.ca/hpcolour.html> Accessed on 18 June 2010.

Lehmann op. cit., p. 145.

T Pakenham. The Boer War. Johannesburg: Jonathan Ball, 1982, 78, 179.

Ibid., pp. 179, 200, 574.

Ibid., pp. 345-6, 361, 457.

J Terraine. White heat: The new warfare 1914-18. London: Book Club Associates, 1982, 146.

33 See FA van Jaarsveld, APJ van Rensburg \& WA Stals. "Voorwoord”. In FA van Jaarsveld, APJ van Rensburg \& WA Stals (eds), Die Eerste Vryheidsoorlog: Van verset en geweld tot skikking deur onderhandeling 1877-1884, Pretoria: HAUM, 1980, vi. Unconfirmed, anonymous observation, Sector 10 Headquarters, Oshakati, August 1981.

J Geldenhuys. A general's story from an era of war and peace. Johannesburg: Jonathan Ball, 1995, 145.

HJ van Aswegen. Geskiedenis van Suid-Afrika tot 1854. Pretoria: Academica, 1989, 32-33; R Elphick, "Die Khoi-Khoi herders". In H Giliomee \& B Mbenga (eds), Nuwe geskiedenis van Suid-Afrika, Cape Town: Tafelberg, 2007, 19-20, 21; R Elphick. Khoikhoi and the founding of white South Africa. Johannesburg: Ravan Press, 1985, 54-55. Die resolusies van die politieke raad van die Kaap van Goeie Hoop. Cape Town Archives Repository, South Africa, C.2, 24-25, 12 July 1659. <http://databases.tanap.net/cgh/> Accessed on 11 May 2012; GM Theal. History of South Africa under the administration of the Dutch East India Company, 1652-1795 I. London: Swan Sonnenschein, 1897, 96-97; Elphick, Khoikhoi and the founding ... op. cit., pp. 96-97, 113-114. H Giliomee. "Weerstand teen koloniale uitbreiding”. In Giliomee \& Mbenga op. cit., pp. 73-74; Van Aswegen op. cit., p. 125. H Giliomee. “The Eastern Frontier”. In R Elphick \& H Giliomee (eds), The shaping of South African society, 1652-1820, Cape Town: Longman, 1979, 297-304; Van Aswegen op. cit., pp. 147, 150; H Giliomee. "Die Xhosa en die Boere”. In Giliomee \& Mbenga op. cit., p. 75.

JG Pretorius. "Hintsa". In WJ de Kock (chief ed), Suid-Afrikaanse biografiese woordeboek I. Cape Town: Tafelberg (for HSRC), 1968, 399401; "This day in history: 12 May 1835: Xhosa King, Hintsa ka Phalo, is killed by British troops". South African History Online.

$<$ http://www.sahistory.org.za/dated-event/xhosa-king-hintsa-ka-phalo-killedbritish-troops $>$ Accessed on 25 August 2011.

H Giliomee. The Afrikaners: Biography of a people. Cape Town: Tafelberg, 2003, 164-165.

See J Laband \& P Thompson. The illustrated guide to the Anglo-Zulu War. Pietermaritzburg: University of Natal Press, 2000 and P Gon. The road to Islandwana: The years of an imperial battalion. Johannesburg: Jonathan Ball, 1992.

See A Wessels. The Anglo-Boer War 1899-1902: White man's war, black man's war, traumatic war. Bloemfontein: Sun Press, 2011. 


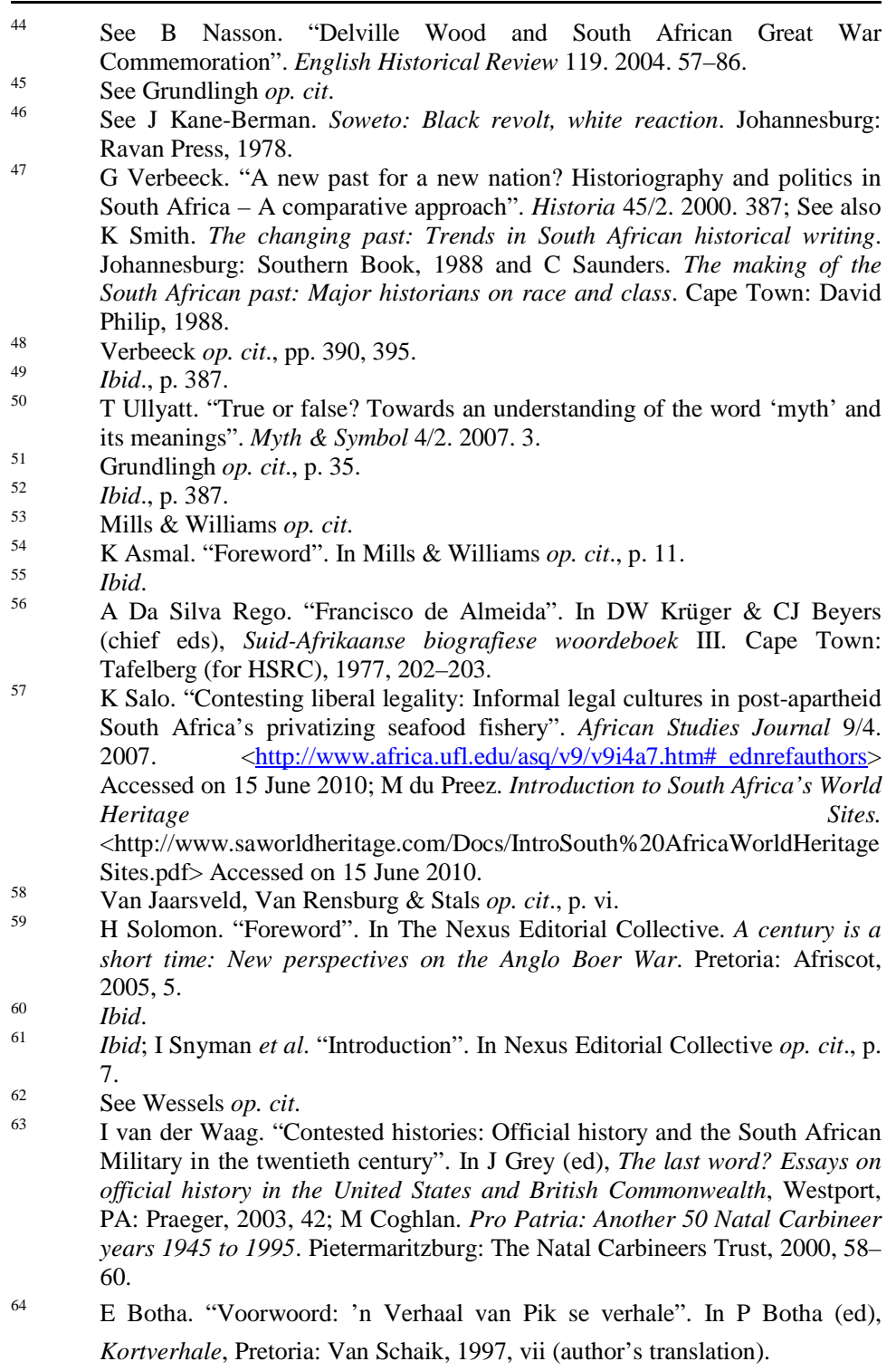


Van der Waag, “Contested histories ...” op. cit., p. 42; Nasson op. cit., pp. 85-86.

Republic of South Africa. Review of defence and armaments production: Period 1960 to 1970. Pretoria: Defence Headquarters, 1971, 5, 9; Republic of South Africa. White Paper on Defence and Armament Production, 1975. Pretoria: Defence Headquarters, 1975, 7; Republic of South Africa. White Paper on Defence and Armaments Supply, 1982. Pretoria: Defence Headquarters, 1982, 1; Grundlingh op. cit., p. 35.

Republic of South Africa. Review of defence ... op. cit., pp. 5, 9.

Van der Waag, “Contested histories ...” op. cit., p. 42; Nasson op. cit., pp. 85-86.

This was done by inter alia distributing Scientia Militaria, the official professional journal of the SADF, which carried articles on these themes, to foreign countries. See for example DM Moore. "SAAF in Korea". Scientia Militaria 10/4. 1980. 24-34, as well as commemorative issues of Scientia Militaria, such as 9/2. 1979 and 17/1-17/3. 1987.

See for example FJ Jacobs \& J Ploeger. "Kleurlinge in militêre verband". Scientia Militaria 4/2. 1974. 39-46, AM le Roux. "Die rol van kleurlinge in Suid-Afrika se militêre verlede”. Scientia Militaria 14/4. 1984. 52-61, CJ Nöthling \& L Steyn. "The role of non-whites in the South African Defence Force”. Scientia Militaria 16/2. 1986. See also Grundlingh op. cit., p. 27.

M Malan. My lewe saam met die SA Weermag. Pretoria: Protea Boekhuis, 2006, 195-198; Geldenhuys op. cit., pp. 92-94.

See inter alia L Scholtz. "Cuito Cuanavale: Wie het werklik gewen?" Scientia Militaria 28/1. 1998; G Mills \& D Williams. "Cuito Cuanavale, 1987-88: Every cause needs a victory”. In Mills \& Williams op. cit.; J Sithole. An epic tale of selfless sacrifices: Cuba's internationalism in Africa, 1962-1991. Pretoria: The Freedom Park Trust, s.a. (c. 2008).

Department of Defence. A decade of peace missions. N.p. (Pretoria): Department of Defence, n.d. (2009); C Ross. "Peace support operations”. SA Soldier 16. 9 September 2009. 10-15.

EW Said. Culture and imperialism. London: Vintage, 1994, 1. Also quoted in I van der Waag \& D Visser. "War, popular memory and the South African literature of the Angolan conflict”. Journal for Contemporary History 34/1. 2009. 139.

C Clapham. From Liberation Movement to government: Past legacies and the challenge of transition in Africa. Johannesburg: The Brenthurst Foundation, 2012, 5.

Hlongwane op. cit., p. 136.

Ibid., pp. 136, 137.

Y Seleti. "December 16, Day of Reconciliation”. In Cleansing and healing [Photographic exhibition], Pretoria, 2006, 6, quoted in Hlongwane op. cit., p. 136.

Ibid.

M Thotse. "Contesting names and statues: Battles over the Louis Trichardt/Makhado 'city-text' in Limpopo Province, South Africa”. Kronos $36 / 1$. 2010. 
$<$ http://www.scielo.org.za/scielo.php?script=sci_arttext\&pid=S0259-

01902010000100008\&lng=en\&nrm=iso> Accessed on 20 November 2012.

81

82

Ibid., p. 178.

Ibid., pp. 178-179.

Department of Defence. "The SANDF Armed Forces day parade and celebrations: 21 February 2012”. Department of Defence News Flash. 7 February 2012. For undisclosed reasons (short notice and/or logistics perhaps?), the very first commemoration, which would inter alia have included a wreath-laying ceremony at the SS Mendi Memorial at the Gamothakga Resort and a Brigade-in-Review Parade at the Atteridgeville Stadium, Pretoria, could not take place on 21 February 2012 and was postponed - see Department of Defence. "Postponement of the Armed Forces day parade - 21 February 2012”. Department of Defence News Flash. 16 February 2012.

Grundlingh op. cit., p. 35.

Department of Defence. "DOD Youth Day Celebrations - 22 June 2012". Department of Defence News Flash. 31 May 2012.

Hlongwane op. cit., p. 166.

Clapham op. cit., p. 6.

Ibid.

Socialist Party of Azania. June 16, 1976: Soweto Uprising commemoration by Black Consciousness Movement. <http://revolutionaryfrontlines.wordpress. com/2010/06/16/june-16-1976soweto-uprising-commemoration-by-black-consciousness-movement/> Accessed on 16 June 2010.

Snyman et al. op. cit., p. 7. Ibid., p. 8; see also Wessels op. cit., pp. 97-134.

A October. "LP spring op haar perdjie oor genl. Botha”. Die Burger. 14 August 2012. 1 (author's translation).

Ibid.

Hlongwane op. cit., p. 137; Thotse op. cit.

See for example P Harper, M Malefane \& F Maponya. “Zuma berates 'alien' Malema”. Sunday Times. 11 April 2010. 1 and S van Wyk. “Ontleders versigtig oor verband tussen liedjie en moord”. Die Burger. 5 April 2010. 3.

Sapa. "Police stop Zille near Kkandla”. news24.com. 4 November 2012. <http://www.news24.com/SouthAfrica/News/Police-stop-Zille-nearNkandla-20121104> Accessed on 20 November 2012.

Ibid.

Wylie, Myth of iron op. cit., p. 508.

Thotse op. cit., p. 179.

S Barber. "Feel-good history”. Sunday Times. 25 February 1996. 